\title{
A CORRELATION BETWEEN VOCABULARY MASTERY AND EMOTIONAL INTELLIGENCE TOWARDS READING COMPREHENSION
}

\section{(A Correlational Study for the State Junior High School Students in Bekasi Regency)}

\author{
Diah Resmisari ${ }^{1}$ \\ diah@stibaiecbekasi.ac.id \\ Sekolah Tinggi Bahasa Asing-IEC Bekasi \\ Julyanta br Sitepu \\ Julyanta@stibaiecbekasi.ac.id \\ Sekolah Tinggi Bahasa Asing-IEC Bekasi
}

\begin{abstract}
Resmisari, D. and Sitepu, J. Br. (2022). A Correlation Between Vocabulary Mastery And Emotional Intelligence
Towards Reading Comprehension (A Correlational Study for the State Junior High School Students in Bekasi Regency). Journal of English Language and literature. Journal of English Language and literature, 7(1), 47-54. doi: 10.37110/jell.v7i1.142
\end{abstract}

Received: 29-01-2022

Accepted: 22-02-2022

Published:03-03-2022

Abstract: This research aims to prove a correlation between Vocabulary Mastery and Emotional Intelligence towards Reading Comprehension (Survey of State Junior High School Students in Bekasi Regency). This research employs a survey of regression and correlation analysis using the SPSS program. There are three variables in this research: two independent variables (vocabulary mastery and emotional intelligence), and one dependent variable (reading comprehension). The data is gathered through vocabulary and reading comprehension tests, as well as a questionnaire on emotional intelligence. Following an analysis of the research variables, the following conclusion can be drawn: (1) There is a significant correlation of vocabulary mastery and emotional intelligence together on students' ability to understand English reading as evidenced by the acquisition of Sig scores. $0.000<$ 0.05 and $\mathrm{Fh}=20.095$ or $29.3 \%$, (2) there is a significant correlation of vocabulary mastery on students' ability to understand English reading as evidenced by the acquisition of Sig scores. $0.002<0.05$ and ttest $=3.164$ or $14.45 \%$, (3) there is a significant correlation of emotional intelligence on the ability to understand students' English reading as evidenced by the acquisition of Sig scores. $0.002<0.05$ and ttest $=3.233$ or $14.87 \%$.

Keywords: Vocabulary Mastery, Emotional Intelligence, English Reading Comprehension

\section{INTRODUCTION}

English is the most language used for communication internationally. It becomes the language of technology, education, politic, commerce, and other purposes. According to Szmigiera (2021) in Statista, one of the leading

${ }^{1}$ Corresponding Author 
online statistics portals, approximately 1.35 billion people worldwide spoke English natively or as a second language in 2021.

Nowadays, information is distributed globally in English via online media such as Google, Wikipedia, Amazon, and YouTube. Additionally, many reference books are available in English. Popular magazines such as Newsweek, Time, Vogue, Bazaar, People, Life, and National Geographic are also published in English, as are scientific journals. Shahab (2001) in the FSU journal in the Limelight wrote that though the students do not major in English, "the students will not be able to avoid reading books in English as the references to improve and advance their knowledge". As a result, the ability to comprehend books written in English is critical and must be mastered by students.

It has been widely accepted for the last fifteen years that reading is one of the most critical skills that students must master to learn English as a second language. Due to the portability of books and other reading materials, reading in stages will be extremely effective for students learning English as a second language in Indonesia, as English native speakers will always be available to provide necessary feedback. (Celce-Murcia, 2001).

For the reasons above, the students need to improve their vocabulary mastery. Thornbury (2006: 1) said:

"All languages have words, Language emerges first as words, both historically, and in terms of the way each of us first and any subsequent languages. The coining of new words never stops. Not does the acquisition of words, and learning new meanings for old words."

A student who lacks vocabulary will struggle to learn a language and will have little success developing their second language. With a sufficient vocabulary, students will find it much easier to acquire all the English skills: listening, reading, speaking, and writing (Burton, 1982:98).

For years, the intelligent quotient (IQ) test has been used to determine students' academic achievement. Another recently discovered intelligence is Emotional Intelligence (EI). Goleman claimed that IQ contributes about $20 \%$ determinant in people's achievements in life. However, EI shares about $80 \%$ of the rest, (Goleman, 1995:32).

Not only IQ, as measured by vocabulary mastery, is critical for reading, but also EI is. Nonetheless, emotional intelligence skills such as perseverance, patience, and accuracy are also required to comprehend English reading material. Ghabanchi and Rastegar (2014: 135) states that there is a significant correlation between reading comprehension and emotional intelligence like interpersonal and intrapersonal ability, as well as stress management.

This research is essential to help the students to improve their vocabulary mastery and emotional intelligence to comprehend reading material in English.

\section{THEORETICAL FRAMEWORK}

\section{a. Reading Comprehension}

Reading is a receptive language skill because it receives information through written media. In reading activities not only is the physical activity involved, but the mind and mental are also actively involved, as in KBBI (2008:113), reading is seeing and understanding the contents of what is written. Reading is a process carried out and used by readers to get the message the author wants to convey through the medium of words/written language. While according to Cole reading is a psychological process that involves sight, eye movements, inner speech, memory, knowledge of understandable words, and the experience of reading to identify the meaning of written words (Wiryodijoyo, 1989:42). Meanwhile according to Ruddel (2005:30) reading is an act of constructing meaning when interacting with texts.

A person is said to comprehend the reading well if he can reveal the meaning of the author's words and expressions, capture the explicit and implied 
meanings, and conclude (Somadoyo, 2011:11). In line with Samsu's opinion, Turner (Somadoyo, 2011:10) states that a reader has a good comprehension of the reading material if he recognizes the words or sentences in the reading and knows their meaning, understands all meaning contextually, and makes judgments about the value of reading content based on his reading experience.

Snow (2002:11) describes reading comprehension as the process of concurrently extracting and producing meaning from written language through interaction and engagement. Reading comprehension is also the result of complex interactions between the text's features and the context in which readers find themselves (Smith, 2004:111). Meanwhile, H.G. Tarigan (1985:12) defines reading comprehension skills as (1) understanding simple meanings (lexical, grammatical, rhetorical); (2) understanding the significance or meaning (the author's intent and purpose, the relevance or cultural circumstances, and the reader's reaction); (3) evaluation or assessment (including content and form); and (4) flexible reading speed that can be easily adapted to ideal circumstances.

Based on the above description, it is concluded that reading comprehension activities can be interpreted as one type of reading activity that can be used to understand the overall contents of the reading, both explicit and implied contents, and carefully understand the overall contents of the reading.

Thus, the essence of reading comprehension is the ability to understand a reading text, in this case, an English reading text, which includes the following aspects: understanding the specific information, detailed information, implied information, word references, word meaning, the main idea of its paragraphs, the topic, and the text's communicative purpose.

\section{b. Vocabulary Mastery}

One of the reasons for knowing a large number of vocabularies is necessary for effective communication. Someone well-versed in the use of vocabulary will find it easier to comprehend a text.

Harmer (1991:153) wrote, "If language structures make up the skeleton of language, then it is the vocabulary that provides the vital organs and the flesh." Thus, vocabulary plays an important role in language use, both orally and in writing. He also explains (2001:16-21) that understanding vocabulary means knowing word meaning, how words extend their use, how words combine, and the grammar of words. There are aspects need discussing: Word meaning variation (synonym, antonym, connotation, and denotation), extending word use (metaphorical words or idiom), word combination (collocation), and the grammar of words (verbs, verbs, adjectives, and adverbs).

Also, different types of vocabulary must be taken into account in vocabulary assessment. Thornburry (2002: 3-10) defines them as follows: word classes or parts of speech; word families; word formation (compounding, blending, conversion, and clipping); multi-word units (primarily phrases and idioms); colocation; homonym; synonym; and antonym.

Nurgiyantoro (2001:213) adds that there are a variety of factors to consider when selecting vocabulary for testing. These aspects are (1) Vocabulary mastery test materials which include: school level and type; difficulty level; both passive and active vocabulary; vocabulary for general, special, and expression; and (2) The vocabulary mastery test levels used using Bloom's taxonomy include: memory level, comprehension level, application level, and analysis level.

To conclude vocabulary mastery refers to the ability to recognize, comprehend, and use words appropriately and correctly when listening, speaking, reading, or writing in a particular language based on grade level or ability-related factors. 


\section{c. Emotional Inteligence}

According to Goleman (2002:512), emotional intelligence is the capacity of an individual to intelligently manage his or her emotional life; to maintain emotional harmony and expression (the appropriateness of emotion and expression) through self-awareness, self-control, self-motivation, empathy, and social skills.

Emotional intelligence also reflects the ability to combine intelligence and emotions to improve thinking. (Mayer, Robert, and Barsade, 2008:511) and is defined as the ability to comprehend emotions and then apply those emotions to improve thinking and intellectual self-development.

Purba (1999:64) agrees with the preceding opinion that emotional intelligence is the capacity for dealing with emotions, specifically the capacity for dealing with frustration, the capacity for controlling emotions, the capacity for optimism, and the capacity for developing relationships with other people, or empathy.

Salovey and Mayer (Goleman, 2002:57) classify emotional intelligence into five categories: selfawareness, self-management, self-motivation, selfawareness of others' emotions, and interpersonal relationships. Goleman adapts Salovey and Mayer's assessment model, which includes five basic emotional skills that are used as indicators for evaluating emotional intelligence variables: (a) Self-awareness (the indicators are self-discovery, rewriting mistakes, views on human position, and feelings after making mistakes); (b) Self Arrangement (the indicators are attitude towards pain, problem-solving, and decision making); (c) Motivation (the indicators are competitive attitudes, future outlook, goal setting, school encouragement, and things that make the spirit live); (d) Empathy (the indicators are responses to the problems of friends, attitudes towards difficult people, views of difficult people); (e) Social Skills (the indicators are the attitude of joining a new community, maintaining social relationships, seeking information from strangers, and speaking in front of large groups).

To summarize, emotional intelligence is the ability to recognize and manage emotions in one's own life as well as in relationships with others. The test for emotional intelligence will include components like self-awareness, self-regulation, motivation, empathy, and social skills.

\section{METHOD}

Because of the nature of the problem and the objectives to be achieved, the research will employ a survey methodology with correlational analysis. Data and information are gathered from respondents in a public junior high school in Bekasi Regency by administering tests and conducting interviews.

Three variables will be used in this research:

(1). Vocabulary mastery (X1);

(2). Emotional Intelligence (X2); and

(3). Reading comprehension (Y).

Vocabulary mastery refers to the ability to recognize, comprehend, and use words appropriately and correctly when listening, speaking, reading, or writing in a particular language based on grade level or ability-related factors. The data is gathered through the administration of a multiple-choice vocabulary test. Operationally, vocabulary mastery can be assessed using a multiple-choice test with up to 25 questions that assess various aspects of comprehension: word meaning, which includes lexical meaning, synonyms, and antonyms; word-extended use, which includes idioms and collocations; and words in grammar. This test is designed to elicit information about students' ability in English vocabulary mastery. Each item correctly answered by the respondent receives a score of one, while each item incorrectly answered receives a score of zero.

Emotional intelligence is the ability to recognize and manage emotions in one's own life as well as in relationships with others. The test for emotional intelligence will include components like self- 
awareness, self-regulation, motivation, empathy, and social skills.

Reading comprehension is the ability to understand a reading text, in this case, an English reading text, which includes the following aspects: understanding the specific information, detailed information, implied information, word references, word meaning, main idea, the topic, and the text's communicative purpose. The test will consist of reading passages followed by multiple-choice questions.

Objective tests are used to collect data on vocabulary mastery (X1) and reading comprehension in English (Y), whereas questionnaires are used to assess students' emotional intelligence (X2).

The correlational analysis is used in this study to determine the instruments' validity. To validate the questions, Pearson Product Moment Correlation will be used. And finally, but not least, to determine the level of significance for the correlation between vocabulary mastery and emotional intelligence concerning reading comprehension, this research will also employ SPSS's Analysis Regression.

\section{RESULT AND DISCUSSION}

The instrument variables for this research are reading comprehension $(\mathrm{Y})$, vocabulary mastery $\left(\mathrm{X}_{1}\right)$, and emotional intelligence $\left(\mathrm{X}_{2}\right)$.

\section{Reading comprehension (Y)}

The data of reading comprehension is collected from 100 junior high school students as the samples of the research. The minimum score is 60 , the maximum score is 95 , the mean score is 80.50 , the median is 80.00 , the mode score is 80 , and the standard deviation score is 8.975 .

\section{Table1. Reading Comprehension}

\begin{tabular}{|c|c|c|}
\hline \multicolumn{3}{|c|}{ Statistics } \\
\hline \multicolumn{3}{|c|}{ Reading Comprehension } \\
\hline \multirow[t]{2}{*}{$\mathrm{N}$} & Valid & 100 \\
\hline & Missing & 0 \\
\hline \multicolumn{2}{|l|}{ Mean } & 80.50 \\
\hline \multicolumn{2}{|l|}{ Median } & 80.00 \\
\hline \multicolumn{2}{|l|}{ Mode } & 80 \\
\hline \multicolumn{2}{|l|}{ Std. Deviation } & 8.975 \\
\hline \multicolumn{2}{|l|}{ Minimum } & 60 \\
\hline \multicolumn{2}{|l|}{ Maximum } & 95 \\
\hline
\end{tabular}

\section{Vocabulary Mastery $\left(\mathrm{X}_{1}\right)$}

The data of vocabulary mastery is obtained from 100 junior high school students. The minimum score is 60 , the maximum score is 95 , the mean score is 80.25 , the median score is 80 , the mode score is 80 , and the standard deviation score is 9.518 . 
Table2

\begin{tabular}{|c|c|c|}
\hline \multicolumn{3}{|c|}{ Vocabulary Mastery } \\
\hline \multicolumn{3}{|c|}{ Statistics } \\
\hline \multicolumn{3}{|c|}{ Penguasaan Kosakata } \\
\hline $\mathrm{N}$ & Valid & 100 \\
\hline & Missing & 0 \\
\hline \multicolumn{2}{|c|}{ Mean } & 80.25 \\
\hline \multicolumn{2}{|c|}{ Median } & 80.00 \\
\hline \multicolumn{2}{|c|}{ Mode } & 80 \\
\hline \multicolumn{2}{|c|}{ Std. Deviation } & 9.518 \\
\hline \multicolumn{2}{|c|}{ Minimum } & 60 \\
\hline \multicolumn{2}{|c|}{ Maximum } & 95 \\
\hline
\end{tabular}

3. Emotional Intelligence $\left(\mathrm{X}_{2}\right)$

The data of Emotional Intelligence is taken from 100 junior high school students. The minimum score is 84 , the maximum score is 122, the mean score is 104.52 , the median score is 104 , the mode score is 104 , and the standard deviation score is 9.344 .

Table3

Emotional Intelligence

\begin{tabular}{|c|c|c|}
\hline \multicolumn{3}{|c|}{ Statistics } \\
\hline \multicolumn{3}{|c|}{ Emotional Intelligence } \\
\hline \multirow[t]{2}{*}{$\mathrm{N}$} & Valid & 100 \\
\hline & Missing & 0 \\
\hline \multicolumn{2}{|l|}{ Mean } & 104.52 \\
\hline \multicolumn{2}{|l|}{ Median } & 104.00 \\
\hline \multicolumn{2}{|l|}{ Mode } & 104 \\
\hline \multicolumn{2}{|l|}{ Std. Deviation } & 9.344 \\
\hline \multicolumn{2}{|l|}{ Minimum } & 84 \\
\hline \multicolumn{2}{|l|}{ Maximum } & 122 \\
\hline
\end{tabular}

Table4

Multiple Coefficient Correlation Test Variable X1 and X2 towards Y.

\begin{tabular}{|l|l|l|l|l|}
\hline Model & $\mathrm{R}$ & R Square & $\begin{array}{l}\text { Adjusted } \\
\text { R Square }\end{array}$ & $\begin{array}{l}\text { Std. Error of the } \\
\text { Estimate }\end{array}$ \\
\hline 1 & $.541^{\mathrm{a}}$ & .293 & .278 & 7.624 \\
\hline a. Predictors: (Constant), Emotional Intelligence, Vocabulary Mastery
\end{tabular}

Table5

The Result of Level Significant of Coefficient Regression Test Variable X1 and X2 towards Y. ANOVA $^{\mathrm{a}}$ 


\begin{tabular}{|l|l|l|l|l|l|l|}
\hline Model & $\begin{array}{l}\text { Sum of } \\
\text { Squares }\end{array}$ & Df & $\begin{array}{l}\text { Mean } \\
\text { Square }\end{array}$ & Sig. \\
\hline Regression & 2336.285 & & 1168.143 & 20.095 & $.000^{\mathrm{b}}$ \\
\hline Residual & 5638.715 & 97 & 58.131 & & \\
\hline \multicolumn{2}{|c|}{ Total } & 7975.000 & 99 & & & \\
\hline
\end{tabular}

Table 6

The Result of Multiple Regression Test Variable X1 and X2 towards Y.

\begin{tabular}{|c|c|c|c|c|c|}
\hline \multicolumn{6}{|c|}{ Coefficients $^{\mathrm{a}}$} \\
\hline \multirow[t]{2}{*}{ Model } & \multicolumn{2}{|c|}{$\begin{array}{l}\text { Unstandardized } \\
\text { Coefficients }\end{array}$} & \multirow{2}{*}{$\begin{array}{l}\text { Standardized } \\
\text { Coefficients } \\
\text { Beta }\end{array}$} & \multirow[t]{2}{*}{$\mathrm{t}$} & \multirow[t]{2}{*}{ Sig. } \\
\hline & $\mathrm{B}$ & $\begin{array}{l}\text { Std. } \\
\text { Error }\end{array}$ & & & \\
\hline (Constant) & 25.228 & 8.986 & & 2.808 & .006 \\
\hline $\begin{array}{l}\text { Vocabulary } \\
\text { Mastery }\end{array}$ & .292 & .092 & .310 & 3.164 & .002 \\
\hline $\begin{array}{l}\text { Emotional } \\
\text { Intelligence }\end{array}$ & .304 & .094 & .317 & 3.233 & .002 \\
\hline
\end{tabular}

As shown in Table 5, there is a significant correlation between vocabulary mastery and emotional intelligence towards reading comprehension. $\mathrm{H}_{0}$ is rejected while $\mathrm{H}_{1}$ is accepted. It is proven by the score of Sig. $0.000<0.05$ and $F_{h}$ $=20.095$.

Meanwhile, the linearity of multiple regression demonstrates that, $\mathrm{Y}=20.095+0.292 \mathrm{X} 1+0.304$ $\mathrm{X} 2$. That is, when the score for one variable, for example, vocabulary mastery or emotional intelligence, increases by approximately 0.292 for $\mathrm{X} 1$ and 0.304 for $\mathrm{X} 2$, it contributes significantly to reading comprehension.

As shown in Table 6, there is a significant correlation between vocabulary mastery and reading comprehension. $\mathrm{H}_{0}$ is rejected while $\mathrm{H}_{1}$ is accepted. It is proven by the score of Sig. $0.008<$ 0.05 and t-test $=3.164$.

Additionally, table 4 demonstrates that vocabulary mastery and emotional intelligence contribute approximately 29.3 percent to reading comprehension.
Correspondingly, the vocabulary mastery variable in relation to reading comprehension will be assessed using the following formula:

$\mathrm{R} 2=$ Score $\beta \_\mathrm{x} 1 \mathrm{y} \times$ Partial Correlation Score (r_x1y) x $100 \%$

$\mathrm{R} 2=0.310 \times 0.466 \times 100 \%=14.45 \%$

According to the above calculation, vocabulary mastery contributes approximately 14.45 percent to reading comprehension.

Table 6 demonstrates the significant contribution of emotional intelligence to reading comprehension. $\mathrm{H}_{0}$ is rejected while $\mathrm{H}_{1}$ is accepted. It is demonstrated by the score of Sig. $0.002<0.05$ and $\mathrm{t}$-test $=3.233$.

The following formula can be used to express the variable of emotional intelligence's contribution to reading comprehension:

$\mathrm{R} 2=$ Score $\beta \_\mathrm{x} 2 \mathrm{y} \times$ Partial Correlation Score (r_x2y) x $100 \%$

$\mathrm{R} 2=0.317 \times 0.469 \times 100 \%=14.87 \%$

According to the calculation above, emotional intelligence contributes approximately 14.87 percent to reading comprehension. 


\section{CONCLUSION}

There is a significant correlation between vocabulary mastery and emotional intelligence towards reading comprehension. It is proven by the score of Sig. $0.000<0.05$ and F-test $=20.095$. The contribution is approximately $29.3 \%$.

There is a significant correlation between vocabulary mastery towards reading comprehension. It is proven by the score of Sig. $0.002<0.05$ and t-test $=3.164$. It contributes approximately $14.45 \%$.

Emotional intelligence contributes significantly towards reading comprehension. It is proven from the score of Sig. $0.002<0.05$ and t-test $=3.233$. The contribution of emotional intelligence will improve reading comprehension by about $14.87 \%$.

\section{REFERENCES}

Burton, S.H. (1982). Mastering English Language. New York: Macmillan.

Celce-Murcia, M. (Penyunting.). (1991). Teaching English as a second or foreign language (3rd Ed.). Washington, DC: Heinle \& Heinle.

Ghabanchi, Z., and Rastegar, Rabe'e. (2014). The Correlation of IQ and Emotional Intelligence with Reading Comprehension. The Reading Matrix Volume 14, Number 2, September 2014.

Goleman, Daniel. (1995). Emotional Intelligence. Jakata: PT Gramedia Pustaka Utama.

Goleman, D. 2002. Emotional Intelligence. Jakata: PT Gramedia Pustaka Utama.

Harmer, J. (2001). The Practice of English Language Teaching: Fourth Edition. Essex: Longman Pearson Education Limited.

(1991). The Practice of English Language Teaching: Third Edition. New York: Longman Publishing.

Mayer, J.D., Roberts, R.D., Barsade, S. (2008). Human Abilities: Emotional Intelligence. Annual Review of Psychology 59: 507-536. https://www.researchgate.net/publication/59070 $\underline{81}$.
Mayer, J.D., Salovey, P., Caruso, D.R. (2004). Emotional Intelligence: Theories, Findings, and Implications. Phsychological Inquiry Vol: 15 No.3 197-215. London: Routledge.

Nurgiyantoro, B. (2001). Penilaian dalam Pembelajaran Bahasa dan Sastra. Bandung: P.T. Kiblat Buku Utama.

Purba, A. (1999). Emotional Intelligence. Seri Ayah Bunda, 26 Juli-8 Agustus. Jakarta: Dian Raya.

Ruddel, M. R. (2005). Teaching Content Reading and Writing. USA: John Wiley \& Sons, Inc.

Shahab, H. (2001). Latar Belakang Kesulitan Membaca Buku Teks Berbahasa Inggris bagi Mahasiswa Bukan Jurusan Bahasa Inggris. FSU in the Limelight Vol. 8, No. 1. http://www.angelfire.com/journal/fsulimelight/ baca.html

Smith, F. (2004). Understanding Reading: Sixth Edition (A Psycholinguistics Analysis of Reading and Learning to Read). New Jersey: Lawrence Erlbraum Associates.

Snow, C. E. (2002). Reading for Understanding: Toward a Research and Development Program in Reading Comprehension. Arlington: RAND.

Somadoyo, S. (2011). Strategi dan Teknik Pembelajaran Membaca. Yogyakarta: Graha Ilmu.

Szmigiera, M. (2021). Statista: Business Data Platform. Hamburg. https://www.statista.com/statistics/266808/themost-spoken-languages-worldwide/

Tarigan, H. G. (1985). Membaca sebagai Suatu Keterampilan Berbahasa. Bandung: Angkasa.

Thornbury, S. (2002). How to teach Vocabulary. Essex: Pearson - Longman.

Tim Penyusun Kamus Pusat Bahasa. (2008). Kamus Besar Bahasa Indonesia (KBBI). Jakarta: Balai Pustaka.

Wiryodijoyo, S. (1989). Membaca: Strategi Pengantar dan Tekniknya. Jakarta: Depdikbud. 